\title{
SADD AL-DZARI'AH:KORELASI DAN PENERAPANNYA DALAM HUKUM EKONOMI SYARIAH
}

\author{
Rukhul Amin \\ Universitas Muhammadiyah Surabaya \\ Email: rukhul.amin@,fai.um-surabaya.ac.id
}

\begin{abstract}
This paper describes the importance of sad al-dzari'ah in determining Islamic law, especially in relation to the business-economy world which tends to be dynamic. Sadd al-dzari'ah is a legal instrument in Islam that is good if it is applied properly, in accordance with the rules of syara '. It can be a tool that can be used to create the benefit of the people and prevent it from being damaged. One example that can be seen in seeing the importance of sadd al-dzariah in the national legal system is the application of the actio paulina principle, the regulations of which can be found in Articles 1341 and 1061 of the Civil Code and Articles 41 to 47 of the bankruptcy law. However, as it plays a very important role in the search for law, on the one hand sadd al-dzari'ah can also be something negative. This can happen if the use or application is not / not done carefully, especially if it is not based on broad social piety in the community.
\end{abstract}

Keyword: Sadd/Fath al-Dzari'ah, Maqashid al-Syariah, Actio Paulina

\section{PENDAHULUAN}

Dalam berbagai literatur ushul fiqh, dalil-dalil syara' seringkali dikelompokkan menjadi adillah alahkam al-muttafaq alaiha (dalil-dalil hukum yang disepakati) dan adillah alahkam al-mukhtalaf alaiha (dalil-dalil yang tidak disepakati / diperselisihkan). ${ }^{1}$ Pada pembagian yang pertama, ijma' dan qiyas, merupakan dua dalil yang secara hierarki mengikuti al-Quran dan al-Sunnah. Walaupun pengertian "disepakati" dalam hal ini memerlukan beberapa perincian, karena ternyata tidak semua ulama memberikan kata sepakat tentang keduanya. $^{2}$

\begin{tabular}{lllr}
\multicolumn{2}{c}{ Kategori } & kedua adalah \\
kelompok dalil & hukum yang \\
keabsaannya & masih & diperselisihkan,
\end{tabular}

1 Abd. Wahab Khalaf, Ilmu ushul al-Fiqh, ( Kairo, Maktabah al-Da'wah al-Islamiah, 1968), h. 20

2 Nasrun Haroen, Ushul Fiqh I, cet. ke 2, (Jakarta: Logos, 1997), h. 18 satu diantaranya adalah sadd aldzari'ah (menutup sarana). Abu Zahrah mensinyalir bahwa Sadd al-dzari'ah adalah metode penggalian hukum Islam yang dapat dilihat perkembangannya dalam mazhab Hanbali dan terutama Maliki. $^{3} \quad$ Al-Qarafi dan asy-Syathibi misalnya, adalah dua ulama bermazhab Maliki yang bisa dijadikan contoh dalam hal ini di samping Ibn Qayyim dari mazhab Hanbali.

Penggunaan sadd al-dzari'ah sebagai salah satu metode penggalian hukum, tentu tidak terlepas dari adanya perubahan sosial yang semakin drastis.

3 Muhammad Abu Zahrah, Ushul al-Fiqh, (Kairo: Dar al-Fikr al-Arabiyah: tt.), h. 228. Lihat pula pernyataan al-Qurthubi tentang hal ini dalam Wahbah az-Zuhaili, Ushul al-Fiqh al-Islami, juz 2, (Beirut: Dar al-Fikr: 1986), h. 893, serta pernyataan ustadz Muhammad Hisyam al-Burhani dalam Ahmad Raisuni, Nadzariyah al-Maqashid inda alImam asy-Syathibi, cet. Ke 4, (Riyadh: Dar al'Alamiah al-Kitab al-Islami/International Islamic Publishing House, 1995), h. 93 
Perubahan tersebut menuntut umat Islam untuk bersikap arif. Produk hukum yang ditetapkan, tidak boleh hanya berfokus pada legal-formal semata, akan tetapi antisipasi terhadap dampak dari tindakan tersebut juga haruslah dipertimbangkan demi mencapai suatu tujuan Syari' yang sesungguhnya (maqashid asy-syari'ah).

Upaya antisipatif, pencegahan dan preventif inilah yang secara sederhana dapat didefiniskan dari sadd dzari'ah. Upaya ini pada suatu kondisi tertentu dianggap urgen karena dapat memberikan respon, jawaban dan solusi yang lebih positif terhadap permasalahan hukum Islam, utamanya bila dikaitkan dengan persoalan sosialekonomi yang cenderung dinamis.

\section{KERANGKA TEORI}

\section{Pengertian Sadd al-Dzari'ah}

Sebelum sampai pada pembahasan definisi secara istilah, ada baiknya mengetahui terlebih dahulu makna kebahasaan dari masing-masing kata. Pemikiran ini merujuk pada kaidah yang menegaskan bahwa hukum asal suatu kalam adalah makna hakikinya. ${ }^{4}$ Term sadd al-dzari'ah (سد merupakan bentuk frase idhafi yang terdiri dari kata sadd (سَد) dan al-

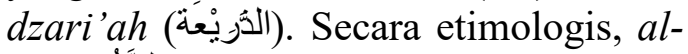
sadd (النَّدُ ) berarti menutup sesuatu yang cacat atau rusak. ${ }^{5}$ Sedangkan aldzari'ah (الدُرِيْعَة) merupakan kata benda bentuk tunggal yang berarti sarana (الوسيّل

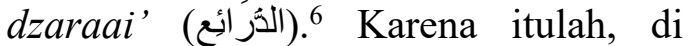
sebagian kitab ushul fiqh, seperti Anwar

\footnotetext{
${ }^{4}$ Husain al-Hasbi, Ushul Fiqh, (Surabaya: Assegaf, t.t.), h. 7

5 Muhammad ibn Mukarram ibn Manzhur alAfriqi al-Mishri, Lisan al-Arab, juz 6, (Beirut: Dar Ehia al-Tourath al-Arabi, t.t), h. 209

${ }^{6}$ Ibid., juz 5, h. 37.
}

al-Buruq fi anwa' al-Furuq karya alQarafi $^{7}$ dan Ushul al-Figh al-Islami karya Wahbah Zuhaili, ${ }^{8}$ istilah yang digunakan adalah adz-dzaraai'.

Pada awalnya al-adzari'ah dipergunakan untuk unta yang dipakai orang Arab dalam berburu. Si unta dilepaskan oleh sang pemburu agar bisa mendekati bintang liar yang sedang diburu. Sang pemburu berlindung di samping unta agar tak terlihat oleh binatang yang diburu. Ketika unta sudah dekat dengan binatang yang diburu, sang pemburu pun melepaskan panahnya. Karena itulah, menurut Ibn al-A'rabi, kata al-dzari'ah kemudian digunakan sebagai metafora terhadap segala sesuatu yang mendekatkan kepada sesuatu yang lain. ${ }^{9}$

Sedangkan secara terminologi, al-Qarafi (684-731 H /1238-1285 M) mendefiniskan sadd al-dzari'ah dengan memotong jalan kerusakan sebagai upaya menghindari kerusakan tersebut. Meski suatu perbuatan bebas dari unsur kerusakan, namun jika perbuatan itu merupakan jalan atau sarana terjadinya suatu kerusakan, maka diharuskan mencegah perbuatan tersebut. ${ }^{10}$

Adapun Ibn Qayyim (691-749 H/1292-1350 M), memaknai aldzari'ah sebagai sarana yang bersifat umum, sehingga kata al-dzari'ah bisa mengandung yang dilarang (sadd aldzari'ah) dan yang dituntut untuk dilaksanakan (fath al-dzari'ah). ${ }^{11}$ Berkenaan dengan pernyataan Ibn Qayyim tersebut, Abd. Karim Zaidan juga berkomentar bahwa pada dasarnya al-dzari'ah berarti sarana atau jalan

\footnotetext{
${ }^{7}$ Syihab ad-Din Abu al-Abbas al-Qarafi, Anwar alBaruq fi Anwa' al-Furuq, juz 2, (Beirut: Dar-alKutub al-Ilmiah, 1998), h. 59

${ }^{8}$ az-Zuhaili, Ushul al-Fiqh..., h. 872

${ }^{9}$ Ibn Manzhur, Lisanul..., h. 37

${ }^{10}$ Al-Qarafi, Anwar al-Buruq..., h. 59

${ }^{11}$ Az-Zuhaili, Ushul al-Fiqh..., h. 872
} 
dengan makna yang umum, akan tetapi pada kebiasaannya lebih banyak diartikan sebagai sarana yang mendatangkan pada kerusakan. ${ }^{12}$

Berbeda dengan pernyataan Ibn Qayyim di atas, al-Syathibi (wafat 790 $\mathrm{H} / 1388 \mathrm{M}$, tanggal dan tahun kelahiran tidak diketahui) mengatakan bahwa aldzari'ah merupakan sarana/pekerjaan yang semula mengandung kemaslahatan tetapi menuju pada kerusakan. Sehingga sadd al-dzari'ah dalam pandangannya berarti menolak sesuatu yang boleh (jaiz) agar tidak mengantarkan pada yang dilarang. ${ }^{13}$ Senada dengan pandangan al-Syatibi, al-Syaukani (1173-1250 H/ 1771-1848 M) juga menyatakan bahwa al-dzari'ah adalah perkara yang pada lahirnya dibolehkan namun akan mengantarkan pada perbuatan yang dilarang. ${ }^{14}$

Dari beberapa pemaparan di atas, al-Qarafi dan Ibn Qayyim menyebutkan al-dzari'ah secara umum dan tidak mempersempitnya hanya sebagai sesuatu yang diperbolehkan. ${ }^{15}$ Lebih lanjut, Ibn Qayyim mengungkapkan adanya al-dzari'ah yang pada awalnya memang dilarang. Akan tetapi sebagian ulama seperti al-Syathibi dan alSyaukani mempersempit cakupan aldzariah hanya pada sesuatu yang awalnya diperbolehkan. Namun yang pasti, bila kata al-dzari'ah diikatkan dengan kata sadd menjadi satu frase idhafi, maka yang bisa dipahami adalah penetapan hukum larangan atas suatu

12 Abd. Karim Zaidan, Al-Wajiz fi Ushul al-Fiqh, (Baghdad: Muassasah Qurtubah, tt), h. 245

13 Ibrahim ibn Musa al-Lakhmi al-Gharnathi alMaliki al-Syathibi, al-Muwafaqat, juz 2, (Beirut: Dar al-Ma'rifah, tt), h. 556

14 Muhammad ibn Ali asy-Syaukani, Irsyad alFuhul fi Tahqiq al-Haqq min 'Ilm al-Ushul, (Beirut: Dar al-Kutub al-Ilmiyyah, 1994), hal. 295

${ }^{15}$ Ungkapan yang populer dari al-Qarafi tentang hal ini adalah "اعلم أن الذريعة كما يجب سدها يجب فتحها " lihat Abu Zahrah, Ushul..., h. 229 perbuatan tertentu yang pada dasarnya diperbolehkan maupun dilarang untuk mencegah terjadinya perbuatan lain yang dilarang.

\section{Ide Dan Dasar Kehujjahan Sadd al-Dzariah}

Ditempatkannya

sebagai salah satu dalil dalam menetapkan hukum, meskipun diperselisihkan penggunaannya, mengandung arti bahwa meskipun syara' tidak menetapkan secara jelas mengenai hukum suatu perbuatan, namun karena perbuatan itu ditetapkan sebagai perantara bagi perbuatan yang dilarang secara jelas, maka hal ini menjadi petunjuk bahwa hukum sarana itu sebagaimana hukum yang ditetapkan syara' terhadap perbuatan pokok. Masalah ini menjadi perhatian ulama, karena banyak ayat al- Qur'an maupun al-hadis yang mengisyaratkan ke arah itu. ${ }^{16}$

Di antara ayat al-Qur'an yang mengandung ide sadd al-dzari'ah adalah QS. al-An'am ayat $108 .{ }^{17}$ Mencaci maki sembahan agama lain, pada ayat tersebut merupakan aldzari'ah (sarana) pada pencacimakian terhadap Allah SWT. Karena itulah, sebelum balasan caci maki itu terjadi, maka larangan mencaci maki tuhan agama lain merupakan tindakan preventif (sadd al-dzari'ah).

Dalam surat al-Baqarah ayat 104 juga disebutkan:

"Hai orang-orang yang beriman, janganlah kamu katakan (kepada Muhammad): "Raa'ina", tetapi katakanlah, "Unzhurna", dan

16 Amir Syarifuddin, Ushul Fiqh, jilid 2, cet. ke 4, (Jakarta: Prenada Media Group, 2008), h. 400

17 Depag RI, Mushaf al-Qur'an Terjemah, (t.tmp, Nur Publishing, t.t.), h. 141 
dengarlah...."

Baqarah:104). ${ }^{18}$

Ayat di atas memberikan pemahaman pada pelarangan terhadap perbuatan karena kekhawatiran terhadap dampak negatifnya. Kata raa ina (رَاعَا) berarti: "Sudilah kiranya kamu memperhatikan kami." Saat para sahabat menggunakan kata ini terhadap Rasulullah, orang Yahudi pun memakai kata ini dengan nada mengejek dan menghina Rasulullah SAW. Mereka menggunakannya dengan maksud kata raa'inan (رَيًَا) sebagai bentuk isim fail dari masdar kata "ru'unah" (رُعَوْنَة) yang berarti "bodoh". ${ }^{19}$ Karenanya, Allah SWT menyuruh para sahabat mengganti kata "raa'ina" dengan "unzhurna" yang juga berarti sama dengan "raa'ina". Dari latar belakang dan pemahaman demikian, ayat ini menurut al-Qurthubi dijadikan dasar dari sadd al-dzari 'ah. ${ }^{20}$

Adapun hadis yang erat kaitannya dengan sadd al-dzari'ah diantarnya: ${ }^{21}$

a) Hadis riwayat dari Abu Muhammad, Hasan ibn 'Ali, telah berkata : "Aku telah menghafal (sabda) dari Rasulullah saw :Tinggalkan apa yang engkau ragukan kepada apa yang tidak engkau ragukan" (HR. Tirmidzi). ${ }^{22}$ Makna dari hadis ini adalah anjuran untuk meninggalkan apa yang menjadikan manusia menuduh atau berprasangka buruk kepada Allah. Hal ini merupakan

${ }^{18}$ Ibid., h. 16

19 Abu Abdillah Muhammad ibn Umar ibn alHasan bin al-Husain at-Taimi ar-Razi, Mafatih alGhaib /Tafsir ar-Razi, juz 2, h. 261 dalam Kitab Digital al-Maktabah asy-Syamilah, versi 2.09

${ }^{20}$ Muhammad ibn Ahmad ibn Abi Bakr ibn Farh Al-Qurthubi, al-Jami' li Ahkam al-Qur'an, juz 2, h. 56 dalam Ibid

${ }^{21}$ Lebih lanjut lihat Abu Zahrah, Ushul..., h. 229

22 Hadis No. 2520. Lihat al-Tirmidzi, Sunan alTirmidzi, juz 9, (Beirut : Dar al-Fikr, 1938), h. 321 fakta yang adil, karena nabi saw melarang orang-orang yang ragu untuk berbuat sesuatu yang ia ragukan, bukan sesuatu yang dirasakan orang-orang darinya. ${ }^{23}$

b) Hadis kedua adalah hadis yang diriwayatkan dari Anas Ibn Malik bahwasanya Rasulullah SAW bersabda: "Apabila salah satu dari kalian meminjami (kepada orang lain) suatu pinjaman, kemudian (orang yang dipinjami) memberi hadiah kepadanya atau memberikan tumpangan atas kendaraannya, maka janganlah dia menaikinya dan jangan (pula) menerimanya." (HR. Ibnu Majah). ${ }^{24}$

Pada dasarnya menerima hadiah bukanlah perbuatan yang terlarang, hal ini sebagaimana diceritakan dalam beberapa hadis tentang kebolehan menerima hadiah, seperti sebuah hadis yang diceritakan dari Sayyidah Aisyah RA. dalam riwayat Al-Bukhari, bahwasanya Nabi SAW . menerima hadiah dan membalasnya. ${ }^{25}$ Akan tetapi, karena kekhawatiran pada adanya riba, maka menerima hadiah dari orang yang berhutang dalam hal ini dilarang.

c) Hadis selanjutnya adalah yang diriwayatkan oleh al-Muslim bahwa Sesungguhnya Nabi saw melarang ihtikar (Menimbun). Maka beliau saw bersabda 'tidak

\footnotetext{
23 Amir Abdul Aziz, Ushul al-Fiqh al-Islami, (Beirut : Dar as-Salam, t.t), h. 489

${ }^{24}$ Hadis No. 2423, Lihat Ibnu Majah, Sunan ibn Majah, kitab ke 14 Bab 838

25 Hadis No: 2585, Lihat Al-Bukhari, Shahih Bukhari
} 
akan menimbun kecuali orang yang salah". (HR. Muslim). ${ }^{26}$

Adanya larangan akan praktek ihtikar (menimbun dengan tujuan merusak pasar) dalam hal ini disebabkan praktek tersebut akan dapat mempersulit masyarakat, baik dalam memperoleh barang-barang yang mereka butuhkan maupun terkait dengan harganya. Namun bila penimbunan itu tidak menimbulkan kemafsadatan maka penimbunan (الإدخار) dalam hal ini tidaklah dilarang.

Dasar lain yang dapat dijadikan pijakan dalam penggunaan sadd aldzari'ah adalah kaidah fiqh "Menolak keburukan (mafsadah) lebih diutamakan daripada meraih kebaikan (maslahah)" 27 Kaidah ini merupakan kaidah asasi yang bisa mencakup masalah turunan di bawahnya. Karena itulah, sadd al-dzari'ah pun bisa disandarkan kepadanya, karena dalam sadd al-dzari'ah terdapat unsur mafsadah yang harus dihindari.

\section{Macam-Macam Al-Dzari'ah}

Secara garis besar, pembagian dzari'ah dapat dikelompokkan menjadi dua bagian. Pembagian tersebut dapat didasarkan pada kualitas kemafsadatannya dan dapat pula dilihat dari jenis kemafsadatannya. ${ }^{28}$

a) Dilihat dari segi kualitas kemafsadatannya. Dalam hal ini alSyatibi membagi al-dzari'ah dalam empat macam bagian:29 a) AlDzari'ah yang membawa pada kerusakan yang pasti; b) AlDzari'ah yang membawa pada

\footnotetext{
${ }^{26}$ Hadis No: 1605, Lihat Muslim al-Hujjaj, Shahih Muslim

27 Jalaluddin as-Suyuthi, al-Asybah wa an-Nazhair, (Beirut: Dar al-Kutub al-Ilmiyyah, tt), hal. 176

${ }^{28}$ Az-Zuhaili, Ushul al-Fiqh..., h. 882-888

${ }^{29}$ Ibid., h. 885-886
}

kerusakan menurut kebiasaannya; c) Al-Dzari'ah yang membawa pada perbuatan terlarang menurut kebiasaannya; dan d) Al-Dzari'ah yang jarang sekali membawa pada kerusakan atau pelarangan.

b) Dilihat dari segi jenis kemafsadatannya. Menurut Ibn Qayyim, al-dzari'ah dari segi ini terbagi pada dua bagian: ${ }^{30}$ a) Perbuatan yang membawa pada kemafsadatan, seperti meminum minuman yang memabukkan, di mana hal itu bisa mendatangkan suatu kemafsadatan; b) Perbuatan tersebut pada dasarnya dibolehkan atau dianjurkan, tetapi dijadikan sarana untuk melakukan perbuatan yang haram, baik dengan tujuan sengaja atau tidak. Ibn Qayyim membagi kembali kedua bagian ini menjadi dua, yaitu: a) yang kemaslahatan pekerjaan itu lebih kuat dari kemafsadatannya dan b) yang kemafsadatannya lebih besar dari kemaslahatannya. Selanjutnya ia membagi lagi kedua pembagian ini menjadi empat bentuk, yaitu: a) Perbuatan yang sengaja ditujukan untuk kemafsadatan; b) Perbuatan yang pada dasarnya dibolehkan, tetapi ditujukan untuk melakukan kemafsadatan; c) Perbuatan yaang secara hukum dibolehkan dan pelakunya tidak bertujuan untuk suatu kemafsadatan, tetapi biasanya akan berakibat suatu kemafsadatan. Misalnya mencaci sesembahan orang musyrik; dan d) Perbuatan yang pada dasarnya dibolehkan, tetapi adakalanya membawa pada suatu kemafsadatan, namun kemaslahatannya lebih besar. Misalnya seperti melihat wanita yang dipinang.

\footnotetext{
${ }^{30}$ Ibid., h. 884
} 


\section{Cara Menentukan Al-Dzari'ah}

Guna menentukan apakah suatu perbuatan dilarang atau tidak, karena ia bisa menjadi sarana (al-dzari'ah) terjadinya suatu perbuatan lain yang dilarang, maka secara umum hal itu bisa dilihat dari dua hal, yaitu: ${ }^{31}$

a) Motif atau tujuan yang mendorong seseorang untuk melaksanakan suatu perbuatan, apakah perbuatan itu akan berdampak kepada sesuatu yang dihalalkan atau diharamkan.

b) Akibat yang terjadi dari perbuatan, tanpa harus melihat kepada motif dan niat si pelaku. Jika akibat atau dampak yang sering kali terjadi dari suatu perbuatan adalah sesuatu yang dilarang atau mafsadah, maka perbuatan itu harus dicegah.

\section{Fath Dzari'ah Dan Muqaddimah}

Dalam kesempatan kali ini perlu pula dikemukakan pembahasan tentang fath adz-dzari'ah sebagai kebalikan dari sadd adz-dzari'ah. Hal ini karena titik tolak yang digunakan adalah adz-dzari'ah. Dalam mazhab Maliki dan Hanbali, adz-dzari'ah memang ada yang dilarang dan ada yang dianjurkan. Hal ini diungkapkan oleh al-Qarafi, yang notabene dari mazhab Maliki dan Ibn Qayyim yang notabene dari mazhab Hanbali. Adzdzari'ah adakalanya dilarang sehingga pelarangan itu disebut sadd adzdzari'ah dan adakalanya dianjurkan atau diperintahkan sehingga anjuran atau perintah itu disebut fath $a d z-$ dzari'ah. ${ }^{32}$

Secara terminologis, bisa dipahami bahwa fath adz-dzari'ah adalah menetapkan hukum atas suatu perbuatan tertentu yang pada dasarnya

\footnotetext{
${ }^{31}$ Al-Zuhaili, Ushul al-Fiqh..., h.879-880

${ }^{32}$ Haroen, Ushul..., h. 171. Lihat pula az-Zuhaili, Ushul..., h. 873
}

tidak diperbolehkan, baik dalam bentuk membolehkan (ibahah), menganjurkan (istihab), maupun mewajibkan (ijab) karena perbuatan tersebut bisa menjadi sarana terjadinya perbuatan lain yang memang telah dianjurkan atau diperintahkan. ${ }^{33}$

Pembahasan tentang fath aldzariah tidak mendapat porsi yang banyak di kalangan ahli ushul fiqih. Hal itu bisa dimaklumi karena fath aldzariah hanyalah hasil pengembangan dari konsep sadd adz-dzari'ah, sementara sadd adz-dzari'ah sendiri tidak disepakati oleh seluruh ulama sebagai metode istinbath hukum. Hal itu karena bagi sebagian mereka, terutama di kalangan ulama Syafi'iyyah, masalah sadd al-dzari'ah dan fath al-dzari'ah masuk dalam bab penerapan kaidah "Jika suatu kewajiban tidak sempurna dilaksanakan tanpa suatu hal tertentu, maka hal tertentu itu pun wajib pula untuk dilaksanakan." 34

Kaidah tersebut berkaitan pula dengan masalah muqaddimah (pendahuluan) dari suatu pekerjaan sebagaimana disebut di atas. Hal ini pula yang menjadi salah satu faktor yang membuat perbedaan pendapat ulama terhadap kedudukan sadd aldzari'ah dan fath al-dzari'ah. Apa yang dimaksudkan al-dzari'ah oleh ulama Maliki dan Hanbali, ternyata bagi ulama Syafi'iyah adalah sekedar muqaddimah (pendahuluan).

Terkait dengan hal ini, Wahbah Zuhaili, mengilustrasikan bahwa muqaddimah adalah laksana fondasi yang mendasari tegaknya dinding, sedangkan al-dzariah adalah laksana

\footnotetext{
${ }^{33}$ Dapat dikoreksi dalam az-Zuhaili, Ushul..., h. 874

34 Muhammad ibn Bahadur bin Abdullah AzZarkasyi, al-Bahr al-Muhith, juz 7 , (Beirut: Dar alKutub al-Ilmiyyah, tt), h. 358
} 
tangga yang menghubungkan ke atap. ${ }^{35}$ Perbedaannya terletak pada ketergantungan perbuatan pokok yang dituju kepada perantaranya. Pada dzari'ah, hukum perbuatan pokok tidak tergantung pada perantara. Ia bisa menjadi suatu perbuatan terpisah yang berdiri sendiri. Sedangkan pada muqaddimah, hukum perbuatan pokok tergantung pada perantara. Dalam hal ini muqaddimah dititikberatkan pada suatu perbuatan hukum yang memang menjadi bagian dari rangkaian perbuatan hukum tertentu. Muqaddimah merupakan perbuatan pendahuluan yang merupakan bagian tak terpisahkan dari rangkaian perbuatan. Misalnya, wudhu merupakan sesuatu perbuatan pendahuluan yang diwajibkan ketika akan melaksanakan shalat. Sementara itu, shalat sendiri merupakan kewajiban. ${ }^{36}$

\section{PEMBAHASAN}

\section{Al-Dzari'ah sebagai Metode Menemukan maqashid al- syari'ah}

Tujuan utama diturunkannya syariat Islam adalah untuk menciptakan kemaslahatan bagi umat manusia, baik masa sekarang maupun mendatang. ${ }^{37}$ Dalam hal ini, hukum Islam harus mampu merepresentasikan dan mewujudkan tujuan-tujuan itu, dengan menghindarkan manusia dari kebinasaan dan kerusakan dan sebaliknya mampu menciptakan unsur keadilan, persamaan, persaudaraan, kebebasan dan kesejahteraan pada semesta alam.

Keadilan dalam perspektif syari'ah, misalnya bukan hanya menyangkut keadilan dalam aspek

\footnotetext{
${ }^{35}$ Az-Zuhaili, Ushul al-Figh..., h. 875

${ }^{36}$ Syarifuddin, Ushul..., h. 399

${ }^{37}$ Ibid., h. 1017
}

hukum, tetapi juga dalam hal keadilan sosial, pemerataan distribusi pendapatan, pengelolaan dan pemanfaatan sumber daya alam, pemerataan kesempatan belajar, bekerja, berusaha dan beraktifitas sosial lainnya. ${ }^{38}$

Dalam hal ini kemaslahatan dalam hukum Islam bersifat dinamis dan fleksibel. Artinya, pertimbangan kemaslahatan itu seiring dengan perkembangan jaman. Konsekuensinya, bisa jadi dianggap maslahah pada satu waktu namun belum tentu masalah pada saat yang lain. ${ }^{39}$

Ringkasnya, pencarian para ahli hukum Islam terhadap kemaslahatan diwujudkan dalam membentuk/meramu suatu metode ijtihad. Berbagai macam istilah telah digunakan oleh mereka untuk menyebut metode penemuan hukum. Namun pada dasarnya, semua metode itu bermuara pada upaya penemuan kemaslahatan dan menjadikannya sebagai alat untuk menetapkan hukum yang kasusnya tidak disebutkan secara eksplisit, baik di dalam al-Qur'an maupun al-Hadis. Atas dasar itulah dapat dikatakan bahwa setiap metode penetapan hukum yang dipakai oleh para ahli ushul fiqh bermuara pada pencarian maqashid al-syari'ah. ${ }^{40}$

Berbicara tentang maqashid alsyari'ah, sebagaimana yang lazim diketahui dalam rumusan Al-Syatibi, ada tiga aspek yang harus dipenuhi

38 Muhammad Zainul Majdi, "Kesempurnaan Syari'at Islam dan Probabilitas Penerapan", Ulumuna, Vol. VII, edisi 11, No. 1 (Januari-Juni 2003), h. 5-6

39 Amir Muallim dan Yusdani, Konfigurasi Pemikiran Hukum Islam, (Yogyakarta: UII Press, 1999), h. 38

40 Fathurrahman Djamil, Metode Ijtihad Majlis Tarjih Muhammadiyah, (Jakarta: Logos Publishing House, 1995), h. 47-48 
dalam pencapaian kemaslahatan tersebut. Pengklasifikasian ini didasarkan pada tingkat kebutuhan dan skala prioritasnya, yaitu:

a) Aspek Daruriyah, yaitu sesuatu yang mesti adanya demi terwujudnya kemaslahatan dunia dan akhirat. Dan ketiadaannya akan menimbulkan kerusakan bahkan hilangnya hidup dan kehidupan. ${ }^{41}$

b) Aspek Hajiyah, yaitu sesuatu yang sebaiknya ada agar dalam melaksanaannya leluasa dan terhindar dari kesulitan. Ketiadaannya tidak akan menimbulkan kerusakan atau kematian, hanya saja akan mengakibatkan masyaqqah dan kesempitan. ${ }^{42}$

c) Aspek Tahsiniyah, yaitu esuatu yang sebaiknya ada demi sesuainya dengan keharusan akhlak yang baik atau dengan adat. Ketiadaaannya tidak akan menimbulkan keusakan atau hilangnya sesuatu juga tidak akan menimbulkan musyaqqah dalam melaksanakannya, hanya saja dinilai tidak pantas dan tidak layak menurut ukuran tata krama dan kesopanan. ${ }^{43}$

Pada hakikatnya, ketiga aspek tersebut bertujuan untuk memelihara lima hal pokok, yaitu ad-din (agama), an-nafs (jiwa), al-aql (akal), an-nasl (keturunan) dan al-mal (harta). Hanya saja, peringkat kepentingannya berbeda satu sama lain. kebutuhan dalam kelompok pertama dapat dikatakan sebagai kebutuhan primer, yang kedua dapat disebut dengan kebutuhan sekunder sedangkan yang ketiga erat kaitannya dengan upaya menjaga etika sesuai dengan kepatutan dan tidak akan

\footnotetext{
${ }^{41}$ Al-Syathibi, al-Muwafaqat, h. 7

${ }^{42}$ Ibid., h. 23

${ }^{43}$ Ibid., h. 45
}

mempersulit apalagi mengancam eksistensi kelima hal pokok di atas. ${ }^{44}$

Di sisi lain, sadd/fath al-dzari'ah adalah salah satu metode penetapan hukum yang bisa dikatakan progresif yang bertumpu pada prinsip-prinsip kemaslahatan yang disimpulkan dari alQur'an dan al-Hadis. Hal ini dapat dimaklumi, karena al-dzari'ah merupakan metode ijtihad yang meletakkan penekanan pada al-nazhar $f i$ al-ma'alat. Sedangkan fokus alnazhar fi al-ma'amalat adalah dengan melihat dampak dari suatu perbuatan, apakah memiliki potensi maslahah atau sebaliknya.

Dengan prinsip al-nazhar fi alma'alat tersebut, maka dapat dilihat bahwa kemaslahatan yang lebih rendah tingkatannya tidak perlu dipertahankan apabila mengakibatkan hancurnya kemaslahatan yang lebih tinggi. Hal ini juga berlaku dalam pemeliharaan kemaslahatan daruriyah yang harus pula melihat kandungan kemaslahatan yang lebih penting di antara lima hal, yaitu: agama, jiwa, akal, keturunan/kehormatan dan harta. ${ }^{45}$

Dalam merealisasikan maqashid alsyari'ah tidak hanya dilihat dalam arti teknis belaka, tetapi juga harus dilihat sebagai upaya dinamika hukum dan sebagai sesuatu yang mengandung nilai filosofis dari hukum-hukum yang disyariatkan Allah Swt terhadap manusia. ${ }^{46}$ Dengan demikian, semua kewajiban (taklif) yang ditetapkan Syari' adalah dalam rangka merealisasikan kemaslahatan hambaNya. Dan dengan prinsip al-nazar fi alma'alat, maka dapat diketahui manakah perbuatan yang memiliki

\footnotetext{
${ }^{44}$ Djamil, Metode Ijtihad..., h. 41

${ }^{45}$ Mu'allim dan Yusdani, Konfigurasi..., h. 62

46 Asafri Jaya Bakri, Konsep Maqashid asySyari'ah menurut al-Syathibi (Jakarta: RajaGrafindo Persada, 1996), h. 65-66
} 
potensi maslahah sehingga ditetapkan fath al-dzari'ah, dan manakah yang berpotensi pada kerusakan, sehingga ditetapkan sadd dzari'ah.

\section{Hubungan Sadd al-Dzari'ah dengan Hukum Ekonomi Syariah}

Untuk mengetahui bagaimana hubungan antara sadd dzari'ah dengan hukum bisnis syariah, setidaknya dapat dilihat dari dua hal berikut ini:

1. Kedudukan Hukum Ekonomi dalam hukum Islam

Ajaran Islam secara garis

besar dapat dibagi ke dalam dua bagian umum yaitu aqidah dan syari'ah (dalam arti sempit). ${ }^{47}$ Syariah dalam arti sempit mencakup akhlak, ibadah dan muamalah (dalam arti luas). ${ }^{48}$

Sedangkan dalam arti yang sempit, muamalah dapat berarti hubungan antara orang individu atau badang hukum dengan orang individu atau badan hukum lain yang melibatkan benda, baik secara langsung maupun secara tidak langsung. Berkaitan dengan ini dikenal pula istilah fiqh muamalah

${ }^{47}$ Pembagian ini sebagaimana yang diutarakan Prof. Samsul Anwar (Guru Besar Syariah UIN Sunan Kalijaga Yogyakarta) saat memberi penjelasan dalam pembahasan tentang kedudukan hukum perikatan. Dalam beberapa literatur dan keterangan terdapat pula pembidangkan ajaran Islam dalam tiga bagian, yaitu akidah, akhlak dan syariah. Sedangkan penggunaan arti sempit dalam hal ini untuk membedakan makna syariah sebagai hukum Islam (kumpulan norma yang mengatur tingkah laku konkret, baik yang disebutkan dalam al-Quran dan Sunnah Nabi saw maupun hasil interpretasi terhadap keduanya) dengan makna syariah dalam arti luas, yaitu agama Islam itu sendiri atau keseluruhan ajaran agama Islam yang dibawa oleh Nabi Muhammad saw.

48 Muamalah dalam arti luas terdiri dari: hukum keluarga, muamalah (arti sempit), hukum pidana, hukum konstitusi, hukum keuangan publik dan hukum hukum internasional. yang berarti kumpulan norma dan ajaran yang mengatur hubunganhubungan dimaksud antar individu atau badan hukum tersebut. Dari pengertian kedua istilah ini dapatlah dicakup beberapa pembahasan didalamnya yaitu hukum badan hukum, hukum benda, hukum perikatan dan hukum bisnis (tijarah). Maka sejauah ini dapatlah ditarik gambaran tentang apa dan dimana posisi hukum bisnis syariah dalam ajaran Islam.

\section{Arti penting sadd al-dzari'ah} dalam pengembangan hukum bisnis syariah

sebagai Posisi hukum bisnis syariah
norma/aturan/hukum Islam yang mengatur hubungan antarmanusia (makhluqat) di bidang perdagangan, perlu mendapat perhatian. Hal ini penting demi mengimbangi perkembangan dunia perdagangan/bisnis yang begitu cepat. Tujuan dari pengaturan norma-norma dalam bermuamalah itu sendiri tidak lain demi menciptakan kemaslahatan di bidang harta, sebagaimana lima macam rumusan kemaslahatan dharuri yang telah disinggung di atas, yaitu memelihara agama, jiwa, akal, keturunan dan harta. ${ }^{49}$ Untuk itu, sadd al-dzari'ah dengan prinsip "an-nazhar fi ma'amalat"nya, memiliki peranan yang sangat penting dalam upaya menciptakan kemaslahatan tersebut.

\section{Prinsip Sadd Al-Dzari'ah dalam Hukum Nasional}

Satu hal yang mengesankan bahwasanya tidak sedikit prinsipprinsip hukum Islam, baik yang

\footnotetext{
${ }^{49}$ Az-Zuhaili, Ushul..., h. 1020
} 
berkaitan dengan hukum secara umum maupun yang langsung berkaitan dengan hukum bisnis, yang sama dalam aturan perundangan Barat, di mana sebagiannya telah diadopsi dalam perundangan nasional Indonesia. Kesamaan ini bisa jadi hanyalah kebetulan belaka, namun tidak menutup kemungkinan hal ini adalah hasil adopsi dari hukum Islam sebelumnya. ${ }^{50}$

Salah satu aturan yang erat kaitannya dengan pembahasan sadd al-dzari'ah kali ini menurut penulis adalah prinsip Actio Paulina, yang pengaturannya dapat kita temukan dalam Pasal 1341 dan 1061 KUHPerdata serta Pasal 41 sampai 47 UU kepailitan. Actio paulina pada prinsipnya merupakan upaya preventif dalam mencegah penyalahgunaan harta. Penyalahgunaan tersebut dapat dilakukan misalnya seperti dalam penghibahan harta sebelum pengajuan pailit yang hal itu dapat mengakibatkan kerugian bagi pihakpihak terkait. ${ }^{51}$

Keberadaan prinsip-prinsip sadd al-dzari'ah dalam perundangan konvensional ini, dapat pula menjadi bukti arti penting sadd al-dzari'ah sebagai metode dalam memberikan solusi penyelesaian persoalan hukum dengan wajah yang lebih humanis.

50 Wacana tentang hal ini dapat dilihat misalnya dalam pemaparan Ignaz Golziher (Le Dogma et la loi de' Islam), Von Kremer (Culture Geshicte des orientalist unter den chalifen), Faiz al-Kuhri (alHuquq al-Rumaniyah), arif al-Naqdi (al-Qadha fi al-Islam), Ahmad Amin (Fajr al-Islam) dan Syafiq Syahanah (al-Nadzariyah al-'Amah Li Iltizami fi alSyar'i al-Islam). Lihat Hendi Suhendi, Fiqh Muamalah, (Jakarta : PT. RajaGrafindo Persada, 2010), h. 5-7

${ }^{51}$ Hadi Subhan, Hukum Kepailitan: Prinsip, Norma dan Praktik di Peradilan, cet. Ke 2, (Jakarta: Prenada Media Group, 2009), h. 176

\section{KESIMPULAN}

Dari beberapa uraian di atas dapatlah kiranya dipahami urgensi sadd/fath dzari'ah dalam penetapan hukum Islam, khususnya yang berkaitan dengan dunia ekonomi-bisnis yang cenderung dinamis. Sadd al-dzari'ah begitu pula fath al-dzariah adalah suatu perangkat hukum dalam Islam yang baik jika diterapkan dengan tepat, sesuai dengan rambu-rambu syara'. Keduanya bisa menjadi perangkat yang bisa digunakan untuk menciptakan kemaslahatan umat dan menghindarkannya dari kerusakan.

Namun, sebagaimana peranannya yang sangat penting dalam upaya penggalian/penetapan hukum, di satu sisi sadd al-dzari'ah juga dapat menjadi sesuatu yang negatif. Hal ini bisa terjadi bilamana penggunaan maupun penerapannya tidak/kurang dilakukan dengan cermat apalagi bila tanpa didasari oleh kesalehan sosial secara luas di tengah masyarakat. 


\section{DAFTARPUSTAKA}

Al-Dzahiri, Ali ibn Ahmad Ibn Sa'id ibn Hazm, Al-Ihkam fi Ushul al-Ahkam, Juz 2, Beirut: Dar al-Kutub al-Ilmiah, t.t.

Al-Mishri, Muhammad ibn Mukarram ibn Manzhur al-Afriqi, Lisan al-Arab, juz 3, Beirut, Dar as-Shadir, t.t.

al-Qarafi, Syihab ad-Din Abu al-Abbas, Anwar al-Baruq fi Anwa' al-Furuq, juz 2, Beirut: Dar-al-Kutub al-Ilmiah, 1998.

Al-Qurthubi, Muhammad ibn Ahmad ibn Abi Bakr ibn Farh, al-Jami' li Ahkam al-Qur'an, juz 2, hal. 56 dalam Kitab Digital al-Maktabah asy-Syamilah, versi 2.09

Al-Razi, Abu Abdillah Muhammad bin Umar bin al-Hasan bin al-Husain at-Taimi, Mafatih al-Ghaib /Tafsir ar-Razi, juz 2, h. 261 dalam Kitab Digital al-Maktabah asy-Syamilah, versi 2.09

Al-Syathibi, Abu Ishak Ibrahim ibn Musa, al-Muwafaqat, juz 2, Beirut: Dar al-Ma'rifah, t.t.

Al-Syaukani, Muhammad ibn Ali, Irsyad al-Fuhul fi Tahqiq al-Haqq min 'Ilm alUshul, Beirut, Dar al-Kutub al-Ilmiyyah, 1994.

Al-Tirmidzi, Sunan at-Tirmidzi, juz 9, Beirut : Dar al-Fikr, 1938

Aziz, Amir Abdul, Ushul al-Fiqh al-Islami, Beirut : Dar as-Salam, t.t.

Bakri, Asafri Jaya, Konsep Maqashid asy-Syari'ah menurut al-Syathibi (Jakarta: RajaGrafindo Persada, 1996

Djamil, Fathurrahman, Metode Ijtihad Majlis Tarjih Muhammadiyah, Jakarta: Logos Publishing House, 1995

Haroen, Nasrun, Ushul Fiqh I, cet. ke 2, Jakarta: Logos, 1997

Khalaf, Abd. Wahab, Ilmu Ushul al-Fiqh, Kairo, Maktabah al-Da'wah al-Islamiah, 1968

Majdi, Muhammad Zainul, "Kesempurnaan Syari'at Islam dan Probabilitas Penerapan", Ulumuna, Vol. VII, edisi 11, No. 1 (Januari-Juni 2003)

Muallim, Amir dan Yusdani, Konfigurasi Pemikiran Hukum Islam, Yogyakarta: UII Press, 1999

Nur Rofiah, “Dr. Elliwarti Maliki: Fiqh-Al-Mar'ah Perspektif Perempuan”, PP Fatayat $N U$, dalam http://www.fatayat.or.id.

Raisuni, Ahmad, Nadzariyah al-Maqashid 'inda al-Imam asy-Syathibi, cet. Ke 4, Riyadh: Dar al-'Alamiah al-Kitab al-Islami/International Islamic Publishing House, 1995

Subhan, Hadi, Hukum Kepailitan: Prinsip, Norma dan Praktik di Peradilan, cet. Ke 2, Jakarta: Prenada Media Group, 2009

Suhendi, Hendi, Fiqh Muamalah, Jakarta : PT. RajaGrafindo Persada, 2010

Syarifuddin, Amir, Ushul Fiqh, jilid 2, cet. 4, Jakarta: Prenada Media Group, 2008

Wahbah Al-Zuhaili, Ushul al-Fiqh al-Islami, juz 2, Beirut: Dar al-Fikr, 1986

Zahrah, Muhammad Abu, Ushul al-Fiqh, Kairo: Dar al-Fikr al-Arabiyah, t.t.

Zaidan, Abd. Karim, Al-Wajiz fi Ushul al-Fiqh, Baghdad: Muassah Qurtubah, t.t. 